\title{
TINGKAT KECUKUPAN ZAT GIZI DAN KADAR HEMOGLOBIN PADA ATLET SEPAKBOLA
}

\author{
Della Annisa Nurdini, Enny Probosari* \\ Program Studi Ilmu Gizi Fakultas Kedokteran Universitas Diponegoro \\ Jln. Prof. H. Soedarto, SH., Semarang, Telp (024) 8453708, Email : gizifk@ undip.ac.id
}

\begin{abstract}
Background: Hemoglobin function is to bind and carry oxygen from the lungs to be circulated throughout the body. Hemoglobin levels can be affected by the intake of protein, iron, folic acid, vitamin C, vitamin A, zinc, copper, tannin and phytate.

Objective: To analyze the relationship of food nutrients intake with hemoglobin levels of football athletes.

Methods: This study was observational with cross sectional approach in Salatiga Training Centre. We enrolled 30 football athletes as subject that drawn by total sampling. All subject were aged 15-18 years. We obtained data: identity, weight, height, and a 24-hour recall. Hemoglobin levels measured by cyanmethemoglobin. Data were analyzed by descriptive analysis, bivariate analysis using Pearson test. Data were tested by linear regression with $\alpha$ \%\%.

Results: All of subjects had a normal hemoglobin level. Iron absorption stimulated by the intake of protein, iron, folic acid, vitamin $C$, vitamin A, zinc, copper with an average intake of successive $64 \pm 8,48 \mathrm{~g}, 72,23 \pm 21,58 \mathrm{mg}, 63,9 \pm 11,34$ $\mathrm{mg}, 78,33 \pm 68,34 \mathrm{mg}, 324,61 \pm 130,3 \mathrm{mg}, 53,5 \pm 8,11 \mathrm{mg}$, and 125,61 $\pm 0,1 \mathrm{mg}$, whereas intake of iron absorption inhibitors consisting of phytate and tannins with a mean of $52.35 \pm 2.1 \mathrm{mg}$ and $1.58 \pm 0.3 \mathrm{mg}$.

Conclusion: This study shows protein, iron, folic acid, vitamin C and zinc adequacy less than 100\%, but vitamin $A$ and copper higher than 100\%. There is a relationship between protein, iron, folic acid, and zinc adequacy to the hemoglobin of football athletes. However, there is no relationship between intake of vitamin $C$, vitamin $A$ and copper to the hemoglobin of football athletes.
\end{abstract}

Keywords: football athlete, hemoglobin, protein, iron, folic acid, vitamin C, vitamin A, zinc, copper

\begin{abstract}
ABSTRAK
Latar Belakang : Hemoglobin berfungsi mengikat dan membawa oksigen dari paru untuk diedarkan ke seluruh tubuh. Kadar hemoglobin dapat dipengaruhi oleh asupan protein, zat besi, asam folat, vitamin C, vitamin A, seng, tembaga, tannin dan fitat.

Tujuan : Menganalisis hubungan tingkat kecukupan zat gizi makanan di asrama atlet dengan kadar hemoglobin atlet sepakbola.

Metode : Penelitian observasional dengan pendekatan cross sectional di Salatiga Training Centre, jumlah sampel 30 atlet usia $15-18$ tahun dengan total sampling. Data yang dikumpulkan meliputi: identitas, berat badan, tinggi badan, dan recall 24 jam. Kadar hemoglobin diukur dengan cyanmethemoglobin. Data dianalisis dengan uji analisis depskripsi, analisis bivariat menggunakan uji pearson. Data diuji dengan regresi linier dengan $\alpha$ 5\%.

Hasil : Sebanyak 100\% subjek mempunyai kadar hemoglobin normal. Pemacu penyerapan besi diantaranya adalah tingkat kecukupan protein, zat besi, asam folat, vitamin $C$, vitamin $A$, seng, tembaga dengan rerata asupan berturut-turut $64 \pm 8,48 \mathrm{~g}, 72,23 \pm 21,58 \mathrm{mg}, 63,9 \pm 11,34 \mathrm{mg}, 78,33 \pm 68,34 \mathrm{mg}, 324,61 \pm 130,3 \mathrm{mg}, 53,5 \pm 8,11 \mathrm{mg}$, dan 125,61 $\pm 0,1$ $\mathrm{mg}$, sedangkan asupan penghambat penyerapan zat besi yang terdiri dari fitat dan tanin dengan rerata $52,35 \pm 2,1 \mathrm{mg}$ dan $1,58 \pm 0,3 \mathrm{mg}$.

Simpulan : Penelitian ini menunjukkan tingkat kecukupan protein, zat besi, asam folat, vitamin $C$, dan seng kurang dari 100\%, sedangkan tingkat kecukupan vitamin A dan tembaga lebih dari 100\%. Terdapat hubungan antara tingkat kecukupan protein, zat besi, asam folat dan seng dengan kadar hemoglobin pada atlet sepakbola. Namun, tidak ada hubungan tingkat kecukupan vitamin C, vitamin A dan tembaga dengan kadar hemoglobin pada atlet sepakbola.
\end{abstract}

Kata kunci : atlet sepakbola, hemoglobin, protein, zat besi, asam folat, vitamin C, vitamin A, seng, tembaga

\section{PENDAHULUAN}

Sepakbola merupakan olahraga ketahanan karena berlangsung selama 90 menit. Daya tahan sangat berperan untuk olahraga yang mempunyai durasi lama, untuk itu diperlukan pasokan energi yang besar. Dalam hal ini, sistem energi yang dominan digunakan adalah sistem energi secara aerobik. Sistem energi secara aerobik adalah sistem energi yang sangat membutuhkan oksigen untuk melakukan pembakaran bahan bakar utama.
Penggunaan oksigen untuk metabolisme secara aerobik harus dipenuhi secara cukup. Oksigen diambil dari alam bebas melalui sistem pernafasan dan akan diedarkan melalui sistem peredaran darah yang diikat oleh hemoglobin. Tingkat kadar hemoglobin sangat berperan dalam menentukan banyaknya jumlah oksigen yang dapat diangkut oleh darah. Semakin banyak oksigen yang dapat diikat maka, metabolisme aerobik akan lancar dalam memproduksi energi yang diperlukan dalam olahraga 
daya tahan. ${ }^{7}$ Tidak cukupnya besi yang masuk dan rendahnya bioavailabilitas makanan yang mengandung besi merupakan penyebab kadar hemoglobin rendah. Pola menu yang bersumber utama dari tepung-tepungan, sayur dan buah yang mengandung penghambat penyerapan besi seperti tannin, phythate, oksalat, phosphate dan serat bila tidak diimbangi dengan mengkonsumsi zat pemacu penyerapan besi seperti besi heme, vitamin $\mathrm{C}$ dan protein, daya tahan pemain dapat menurun. ${ }^{1}$

Hemoglobin berfungsi mengikat dan membawa oksigen dari paru untuk diedarkan ke seluruh tubuh. Penurunan jumlah oksigen dalam tubuh dipengaruhi oleh konsentrasi hemoglobin. Pada saat melakukan metabolisme, tubuh memerlukan oksigen untuk menghasilkan energi. Semakin lama dan tinggi aktivitas yang dilakukan seseorang maka jumlah oksigen yang diperlukan untuk metabolisme akan meningkat. Menurut penelitian yang dilakukan di sekolah sepakbola Anyelir dan sekolah sepakbola Bangau didapatkan 46,7\% dan 47,6\% atlet sepakbola mengalami anemia. ${ }^{2}$

Usia remaja merupakan masa dimana pertumbuhan dan perkembangan pada titik yang maksimal. Usia 15 - 18 tahun dapat dilakukan penelitian karena dapat menjadi upaya pencegahan anemia. Jika konsentrasi hemoglobin dalam tubuh rendah akan menyebabkan penurunan angka maksimal pengiriman oksigen ke jaringan tubuh, sehingga akan berakibat pada penurunan jumlah energi yang dihasilkan untuk melakukan aktivitas. ${ }^{3}$

Penyelenggaraan makanan bagi atlet di asrama sangat penting untuk kebutuhan zat gizi atlet. Seorang atlet yang baik harus makan makanan tinggi karbohidrat, cukup protein, rendah lemak, dan cukup vitamin, mineral serta cairan. ${ }^{4}$ Kadar hemoglobin rendah dapat dipengaruhi oleh asupan zat gizi yang kurang. Ketersediaan asupan makan sumber zat besi dalam bentuk bahan makanan, cairan maupun suplemen dapat meningkatan kadar hemoglobin, hematokrit, dan sel darah merah. ${ }^{5}$ Asupan makronutrien seperti protein berperan pada penyimpanan dan transportasi zat besi. Selain itu dalam penyerapan zat besi di usus halus juga dibantu oleh Heme Carrier Protein (HCP1). ${ }^{6}$ Zat besi merupakan komponen utama yang memegang peranan penting dalam pembentukan darah (hemopoiesis) yaitu mensintesis hemoglobin. ${ }^{7}$ Selain asupan zat besi, mikronutrien seperti seng, tembaga, folat, vitamin $\mathrm{C}$ dan juga vitamin $\mathrm{A}$ juga berhubungan dengan kadar hemoglobin pada tubuh. Asupan makanan selain dari asrama juga perlu untuk diperhatikan terkait dengan jumlah asupan zat gizi yang masuk ke dalam tubuh atlet. ${ }^{8}$

Berdasarkan latar belakang tersebut, peneliti tertarik untuk meneliti hubungan tingkat kecukupan zat gizi makanan dengan kadar hemoglobin atlet sepakbola.

\section{METODE}

Penelitian ini menggunakan rancangan penelitian cross sectional study dengan ruang lingkup gizi masyarakat. Populasi dalam penelitian ini adalah seluruh atlet usia 15-18 tahun di Salatiga Training Centre. Penelitian ini mengunakan total sampling dengan menjadikan semua populasi sebagai subjek penelitian.

Kriteria inklusi dalam penelitian ini adalah bersedia menjadi subjek penelitian yang dibuktikan dengan mengisi informed consent, berusia $15-18$ tahun dan merupakan atlet sepakbola Salatiga Training Centre. Kriteria eksklusi pada penelitian ini adalah subjek yang mengundurkan diri selama penelitian berlangsung.

Data yang didapatkan meliputi data identitas sampel, antropometri, asupan protein, zat besi, asam folat, vitamin C, vitamin A, seng dan tembaga, serta data hasil laboratorium untuk kadar hemoglobin atlet. Asupan protein, zat besi, asam folat, vitamin C, vitamin A, seng, dan tembaga diperoleh dengan menggunakan recall 24 jam selama 10 hari. Data identitas sampel meliputi nama, tanggal lahir, jenis kelamin, dan alamat yang didapat dari formulir identitas sampel. Data antropometri meliputi tinggi badan badan yang diukur menggunakan mikrotoa dengan ketelitian $1 \mathrm{~cm}$ dan berat badan menggunakan timbangan digital dengan ketelitian 0,1 gram.

Gambaran status gizi atlet sepakbola usia 1518 tahun menggunakan z-score IMT/U yang diklasifikasikan menjadi 5, yaitu: sangat kurus ( $z$ score < -3 SD), kurus ( $-3 \mathrm{SD} \leq z$-score $<-2 \mathrm{SD})$, normal $(-2 \mathrm{SD} \leq z$-score $<+1 \mathrm{SD})$, gemuk $(+1 \mathrm{SD} \leq$ $z$-score $<+2 \mathrm{SD})$, dan obesitas ( $z$-score $\geq+2 \mathrm{SD})$,

Tingkat kebutuhan asupan protein subjek dihitung menggunakan $15 \%$ dari kebutuhan energi yang menggunakan rumus khusus atlet, sedangkan tingkat kebutuhan zat besi, asam folat, vitamin C, vitamin A, seng, dan tembaga subjek dikategorikan berdasarkan Angka Kecukupan Gizi (AKG) 2013.

Tingkat kecukupan protein, zat besi, asam folat, vitamin $\mathrm{C}$, vitamin $\mathrm{A}$, seng dan tembaga pada penelitian ini dibagi menjadi tiga kategori, yaitu kurang, cukup dan lebih. Kategori tingkat kecukupan protein kurang apabila $<80 \%$ dari tingkat kecukupan protein berdasarkan kebutuhan masing-masing atlet yang dihitung berdasarkan rumus kebutuhan energi atlet berdasarkan buku pedoman gizi olahraga dari Kementrian Kesehatan Republik Indonesia (Kemenkes RI) yang dihitung dengan memperhatikan beberapa komponen yaitu energi Basal Metabolic Rate (BMR), Specific Dynamic Action (SDA), 
Aktivitas Fisik, Energy Expenditure untuk setiap jenis dan lama latihan.

Kategori tingkat kecukupan zat besi, asam folat, vitamin C, vitamin A, seng dan tembaga kurang apabila $<100 \%$ dari kebutuhan zat besi, asam folat, vitamin $\mathrm{C}$, vitamin $\mathrm{A}$, seng dan tembaga menurut AKG. Kebutuhan asupan besi dan asam folat untuk atlet usia 15 - 18 tahun adalah $15-19 \mathrm{mg}$ per hari dan $400 \mathrm{mg}$ per hari. Selain itu, kebutuhan asupan vitamin C, vitamin A, seng dan tembaga adalah $75-90 \mathrm{mg}$, $600 \mathrm{mcg}, 17-18 \mathrm{mg}$, dan 0,8-0,89 mg per hari.

Data diuji normalitasnya dengan uji One

Sample Kolmogorov Sminov. Analisis data uji hubungan menggunakan uji korelasi Pearson.

\section{HASIL}

\section{Karakteristik Subjek Penelitian}

\section{Analisis Univariat}

Penelitian ini terdapat 30 subjek penelitian yang mengikuti dari awal sampai akhir penelitian. Distribusi status gizi atlet dapat dilihat pada tabel 1 dan rerata usia, berat badan, tinggi badan, dan kadar hemoglobin disajikan dalam tabel 2. Distribusi frekuensi status gizi menunjukkan bahwa 30 atlet $(100 \%)$ memiliki status gizi normal.

Tabel 1. Distribusi Status Gizi dan Usia

\begin{tabular}{lcc}
\hline & n & Presentase (\%) \\
\hline Status Gizi (IMT/U) & & \\
Sangat Kurus & 0 & 0 \\
Kurus & 0 & 0 \\
Normal & 30 & 0 \\
Gemuk & 0 & 0 \\
$\quad$ Obesitas & 0 & \\
Usia & & 23,3 \\
15 tahun & 7 & 50 \\
16 tahun & 15 & 20 \\
17 tahun & 6 & 6,7 \\
18 tahun & 2 & \\
\hline
\end{tabular}

Kadar Hemoglobin, Tingkat Kecukupan Asupan Protein, Zat Besi, Asam Folat, Vitamin C, Vitamin A, Seng, Tembaga, Tannin dan Fitat
Kadar hemoglobin, tingkat kecukupan asupan protein, zat besi, asam folat, vitamin C, vitamin A, seng, tembaga, tannin dan fitat seperti yang tersaji pada tabel 2 .

Tabel 2. Kadar Hemoglobin, Tingkat Kecukupan Asupan Protein, Zat Besi Asam Folat, Vitamin C, Vitamin A, Seng, Tembaga, Tannin dan Fitat

\begin{tabular}{lcc}
\hline Tingkat Kecukupan & n & Rerata \pm SD \\
\hline Kadar Hemoglobin (gr/dL) & 30 & $14,5 \pm 0,74$ \\
Protein (\%) & 30 & $64 \pm 8,48$ \\
Zat besi (\%) & 30 & $72,23 \pm 21,58$ \\
Asam Folat (\%) & 30 & $63,9 \pm 11,34$ \\
Vitamin C (\%) & 30 & $78,33 \pm 68,34$ \\
Vitamin A (\%) & 30 & $324,61 \pm 130,3$ \\
Seng (\%) & 30 & $53,5 \pm 8,11$ \\
Tembaga (\%) & 30 & $125,61 \pm 0,1$ \\
Tanin (mg) & 30 & $52,35 \pm 21,49$ \\
Fitat (mg) & 30 & $1,58 \pm 0,32$ \\
\hline
\end{tabular}

Tabel 2 menunjukkan nilai mean dan standar deviasi dari tingkat kecukupan protein, zat besi, asam folat, vitamin $\mathrm{C}$, vitamin $\mathrm{A}$, seng, tembaga, serta asupan tannin dan fitat. Nilai mean tingkat kecukupan protein, zat besi, asam folat, vitamin $\mathrm{C}$, seng ada dibawah nilai kebutuhan sedangkan nilai mean vitamin A dan tembaga memenuhi kebutuhan.

Distribusi tingkat kecukupan protein, zat besi, asam folat, vitamin $\mathrm{C}$, vitamin $\mathrm{A}$, seng dan tembaga dapat dilihat dalam tabel 3 . 
Tabel 3. Distribusi Tingkat Kecukupan Protein, Zat Besi, Asam Folat, Vitamin C, Vitamin A, Seng, dan Tembaga

\begin{tabular}{|c|c|c|}
\hline Variabel & $\mathbf{n}$ & Presentase $(\%)$ \\
\hline \multicolumn{3}{|l|}{ Kadar Hemoglobin } \\
\hline Normal (>13 gr/dL) & 30 & 100 \\
\hline Kurang $(<13$ gr/dL) & 0 & 0 \\
\hline \multicolumn{3}{|c|}{ Tingkat kecukupan Protein (g) } \\
\hline Kurang $(<80 \%)$ & 30 & 100 \\
\hline Cukup $(80-100 \%)$ & 0 & 0 \\
\hline Lebih $(>100 \%)$ & 0 & 0 \\
\hline \multicolumn{3}{|c|}{ Tingkat kecukupan Zat Besi (mg) } \\
\hline Kurang $(<100 \%)$ & 27 & 90 \\
\hline Cukup (100\%) & 0 & 0 \\
\hline Lebih $(>100 \%)$ & 3 & 10 \\
\hline \multicolumn{3}{|c|}{ Tingkat kecukupan Asam Folat (mg) } \\
\hline Kurang $(<100 \%)$ & 30 & 100 \\
\hline Cukup (100\%) & 0 & 0 \\
\hline Lebih $(>100 \%)$ & 0 & 0 \\
\hline \multicolumn{3}{|c|}{ Tingkat kecukupan Vitamin C (mg) } \\
\hline Kurang $(<100 \%)$ & 27 & 90 \\
\hline Cukup (100\%) & 0 & 0 \\
\hline Lebih $(>100 \%)$ & 3 & 10 \\
\hline \multicolumn{3}{|c|}{ Tingkat kecukupan Vitamin A (mcg) } \\
\hline Kurang $(<100 \%)$ & 3 & 10 \\
\hline Cukup (100\%) & 0 & 0 \\
\hline Lebih $(>100 \%)$ & 27 & 90 \\
\hline \multicolumn{3}{|c|}{ Tingkat kecukupan Seng (mg) } \\
\hline Kurang $(<100 \%)$ & 30 & 100 \\
\hline Cukup (100\%) & 0 & 0 \\
\hline Lebih $(>100 \%)$ & 0 & 0 \\
\hline \multicolumn{3}{|c|}{ Tingkat kecukupan Tembaga (mg) } \\
\hline Kurang $(<100 \%)$ & 0 & 0 \\
\hline Cukup $(100 \%)$ & 0 & 0 \\
\hline Lebih $(>100 \%)$ & 30 & 100 \\
\hline
\end{tabular}

Berdasarkan tabel 3 diketahui bahwa kadar hemoglobin normal sebesar 10 atlet $(33,3 \%)$, sedangkan kadar hemoglobin kurang sebesar 20 atlet $(66,7 \%)$. Tingkat kecukupan protein, asam folat dan seng seluruh atlet (100\%) kurang, sedangkan tingkat kecukupan tembaga seluruh atlet $(100 \%)$ lebih. Tingkat kecukupan zat besi dan vitamin $\mathrm{C}$ sebagian besar tergolong kurang sebanyak 27 atlet (90\%), hanya 3 atlet $(10 \%)$ tergolong lebih. Berbeda dengan tingkat kecukupan vitamin $\mathrm{C}$ dan zat besi, tingkat kecukupan vitamin A sebagian besar lebih sebanyak 27 atlet (90\%), hanya 3 atlet (10\%) tergolong kurang. Hubungan Antar Variabel

Hubungan tingkat kecukupan protein, zat besi, asam folat, vitamin $\mathrm{C}$, vitamin $\mathrm{A}$, seng dan tembaga dengan kadar hemoglobin tersaji dalam tabel 4.
Tingkat kecukupan protein, zat besi, asam folat dan seng menunjukkan hubungan yang signifikan dengan kadar hemoglobin. Sedangkan vitamin C, vitamin A dan tembaga menunjukkan tidak ada hubungan yang signifikan dengan kadar hemoglobin. Asupan tannin menunjukkan hubungan yang terbalik dengan kadar hemoglobin karena $\mathrm{r}$ menunjukkan tanda negatif.

Asupan zat gizi perancu pada penelitian ini yaitu asupan tannin dan fitat. Setelah dilakukan uji korelasi, asupan tannin dan fitat tidak memiliki hubungan yang signifikan dengan kadar hemoglobin. Namun, setelah adanya uji multivarat, keduanya tidak secara signifikan menjadi perancu. 
Tabel 4. Hubungan Tingkat Kecukupan Asupan Protein, Zat Besi, Asam Folat, Vitamin C, Vitamin A, Seng dan Tembaga dengan Kadar Hemoglobin

\begin{tabular}{lcc}
\hline \multirow{2}{*}{ Variabel } & \multicolumn{2}{c}{ Nilai Parameter } \\
\cline { 2 - 3 } & $\mathbf{r}$ & $\boldsymbol{p}$ \\
\hline Protein & 0,391 & $0,032^{*}$ \\
Zat besi & 0,414 & $0,023^{*}$ \\
Asam Folat & 0,375 & $0,041^{*}$ \\
Vitamin C & 0,117 & 0,538 \\
Vitamin A & 0,132 & 0,486 \\
Seng & 0,378 & $0,039^{*}$ \\
Tembaga & 0,192 & 0,308 \\
Tannin & $-0,052$ & 0,785 \\
Fitat & 0,317 & 0,087 \\
\hline
\end{tabular}

$* p$ value $<0,05$

\section{PEMBAHASAN}

\section{Karakteristik Subjek Penelitian}

Anemia adalah kondisi dimana jumlah sel darah merah (kapasitas pembawa oksigen) tidak mencukupi untuk kebutuhan tubuh. Defisiensi besi merupakan penyebab paling sering untuk kejadian anemia, namun defisiensi zat gizi lain, inflamasi akut dan kronik, infeksi parasit, dan gangguan dalam sintesis hemoglobin, produksi sel darah merah, kelangsungan hidup sel darah merah dapat pula menyebabkan anemia. ${ }^{9}$

Berdasarkan besar subjek sebanyak kadar hemoglobin normal sebesar 10 atlet $(33,3 \%)$, sedangkan kadar hemoglobin kurang sebesar 20 atlet $(66,7 \%)$. Akan tetapi, asupan zat gizi yang berpengaruh pada kadar hemoglobin menunjukkan bahwa atlet sepakbola kurang memenuhi kecukupan zat gizi tersebut. Asupan protein, asam folat, dan seng menunjukkan bahwa seluruh atlet sepakbola Salatiga Training Centre yang menjadi subjek penelitian berada pada kategori kurang. Selain itu, sebagian besar asupan zat besi dan vitamin $\mathrm{C}$ menunjukkan berada dalam kategori kurang, dan hanya terdapat 3 atlet $(10 \%)$ yang berada dalam kategori cukup dan lebih. Namun, kategori lebih ditunjukkan pada asupan tembaga seluruh atlet sepakbola.

\section{Hemoglobin}

Hemoglobin merupakan parameter yang paling umum digunakan untuk menetapkan prevalensi anemia. Penentuan kadar hemoglobin dengan nilai batas untuk anemia yang digunakan menurut WHO, 2001 adalah untuk umur $5-11$ tahun $<11,5 \mathrm{~g} / \mathrm{L}, 11$ -14 tahun $<12 \mathrm{~g} / \mathrm{L}$, remaja diatas 15 tahun untuk anak perempuan $<12 \mathrm{~g} / \mathrm{L}$ dan laki-laki $13 \mathrm{~g} / \mathrm{L}{ }^{10}$

Status hemoglobin dapat mempengaruhi prestasi dan aktifitas siswa termasuk dalam berolahraga. ${ }^{12} \mathrm{Hal}$ ini dapat dijelaskan karena apabila seseorang mengalami anemia, maka aktifitasnya menjadi berkurang. Anemia dapat mengakibatkan kurangnya oksigen yang ditransportasikan ke sel tubuh maupun otak, sehingga menimbulkan gejala letih, lesu dan cepat lelah. ${ }^{13}$ Akibatnya dapat menurunkan kebugaran dan prestasi pada atlet.

Seorang atlet memerlukan oksigen yang lebih banyak untuk pembakaran karbohidrat yang menghasilkan energi terutama pada saat berlatih atau bertanding. Untuk mengangkut oksigen $\left(\mathrm{O}_{2}\right)$ ke otot diperlukan hemoglobin atau sel darah merah yang cukup. Untuk membentuk hemoglobin yang cukup tubuh memerlukan zat besi (Fe) yang bersumber dari daging (dianjurkan daging yang tidak berlemak), sayuran hijau dan kacang-kacangan. ${ }^{14}$ Selain itu, asupan protein, asam folat, vitamin $\mathrm{C}$, vitamin $\mathrm{A}$, seng dan tembaga merupakan zat gizi yang berpengaruh pada metabolisme hemoglobin, sedangkan fitat dan tanin merupakan zat penghambat penyerapan zat besi.

Berdasarkan hasil penelitian yang dilakukan, kadar hemoglobin pada atlet sepak bola yang memiliki kadar hemoglobin normal sebesar 30 atlet $(100 \%)$ dari Salatiga Training Centre. Kadar hemoglobin yang normal membuat atlet memiliki kesehatan optimum dan kemampuan fisik yang memungkinkan mereka untuk bertahan dalam latihan fisik yang keras dan mampu mempertahankan penampilan yang baik selama pertandingan. ${ }^{2}$

Hubungan Asupan Protein, Zat Besi, Asam Folat, Vitamin C, Vitamin A, Seng, dan Tembaga dengan Kadar Hemoglobin

Penelitian ini didapatkan hasil bahwa terdapat hubungan positif antara asupan protein, zat besi, asam folat dan seng dengan kadar hemoglobin. Penelitian ini sejalan dengan penelitian yang dilakukan oleh Sugiyanto dengan subjek anak sekolah, diketahui terdapat hubungan kontribusi asupan protein, asam folat, dan tannin dengan kadar hemoglobin anak SD. Namun, berbanding terbalik pada asupan vitamin C yang justru menunjukkan tidak ada hubungan dengan kadar hemoglobin. Selain itu, penelitian lain menunjukkan bahwa ada hubungan signifikan antara asupan protein dengan kadar hemoglobin pada anak usia $1-3$ tahun. 
Asupan protein berperan pada penyimpanan dan transportasi zat besi. ${ }^{6}$ Selain itu, protein merupakan salah satu komponen yang berperan dalam pembentukan darah merah. Protein transferin berperan dalam pengangkutan besi ke sumsum tulang dalam rangka pembentukan molekul hemoglobin yang baru. ${ }^{15}$ Protein diperlukan sebagai bahan awal sintesis heme yaitu asam amino glisin. ${ }^{16}$ Protein diperlukan pada kondisi cukup. Namun, pada penelitian kali ini diketahui bahwa asupan protein seluruh atlet berada dalam kategori kurang. Hal ini dapat terjadi karena penyediaan makanan di asrama dalam beberapa menu kurang sesuai dengan porsi ukuran rumah tangga, khususnya sumber protein. Protein nabati dalam beberapa menu tidak terdapat dalam menu. Selain itu, sumber protein hewani mempunyai berat yang kurang sesuai dengan standar ukuran rumah tangga.

Hal itu juga dapat terjadi pada sumber zat besi dan seng yang sebagian besar tergolong kategori kurang. Zat besi merupakan komponen utama yang memegang peranan penting dalam pembentukan darah (hemopoiesis) yaitu mensintesis hemoglobin. ${ }^{6}$ Seng diperlukan untuk sintesis hemoglobin dan berpengaruh pada metabolisme zat besi. Seng diabsorpsi oleh usus melalui mekanisme Divalent Metal Transporter-1 (DMT-1) yang juga transporter zat besi dan mineral lain dalam usus. Adanya kesamaan transporter antara zat besi dan zat seng mengakibatkan absorpsi antara zat besi dan zat seng saling mempengaruhi satu sama lain. ${ }^{17}$ Penyerapan seng dapat terganggu oleh zat besi bila diminum dengan media larutan karena keduanya berkompetisi pada jalur penyerapan yang sama. Namun keadaan ini tidak terjadi bila dikonsumsi bersama dengan makanan, karena seng akan diserap melalui jalur alternatif lain dengan bantuan ligan yang terbentuk selama pencernaan protein. ${ }^{18,19,20}$

Asupan asam folat seluruh atlet tergolong kurang. Penyebabnya sama dengan asupan zat gizi lainnya, yaitu kurang dalam mengonsumsi sumber bahan makanan yang mengandung asam folat. Folat berperan sebagai pembawa karbon tunggal dalam pembentukan heme ${ }^{21}$, sehingga sangat berperan penting pada kadar hemoglobin. Katering atlet telah menyediakan sayur-sayuran dalam menu makanan bagi atlet. Namun, dalam penyajiannya kurang menarik sehingga atlet tidak tertarik untuk mengonsumsinya. Selain itu, banyak atlet yang tidak suka dengan makanan yang berbahan dasar sayur.

Asupan vitamin $\mathrm{C}$, vitamin A dan tembaga dalam penelitian ini tidak berhubungan dengan kadar hemoglobin atlet. Asupan vitamin $\mathrm{C}$ sebagian besar tergolong kurang. Vitamin $\mathrm{C}$ mudah rusak bila dalam keadaan larut karena bersentuhan dengan udara (oksigen) terutama bila terkena panas. ${ }^{22}$ Oksidasi dipercepat dengan kehadiran tembaga, dimana asupan tembaga seluruh atlet tergolong lebih. Penelitian ini sejalan dengan penelitian yang dilakukan oleh Anggraini di Makassar dengan subjek ibu hamil. Hal ini dapat terjadi karena penyediaan buah pada menu makanan atlet hanya 1 porsi setiap harinya. Vitamin $\mathrm{C}$ termasuk dalam faktor pemacu penyerapan besi dalam tubuh dan berperan dalam mereduksi besi feri menjadi fero dalam usus halus sehingga mudah diabsorpsi. ${ }^{22}$

Berbeda dengan vitamin $\mathrm{C}$, asupan vitamin A seluruh atlet tergolong lebih. Hal ini dapat terjadi karena dalam beberapa menu makanan atlet banyak terdapat sumber vitamin A, termasuk hati ayam yang mempunyai kandungan vitamin A yang tinggi. Namun, tidak ada hubungan yang signifikan dengan kadar hemoglobin. Vitamin A berperan dalam mobilisasi zat besi dari hepar. Kekurangan zat besi dalam tubuh dapat mengganggu metabolisme vitamin A dengan mengurangi mobilisasi vitamin A dari penyimpanan dalam hati dan mengurangi penyerapan retinol. ${ }^{23}$ Begitu juga dengan penelitian Yoni di Klaten yang menunjukkan bahwa tidak ada hubungan vitamin A dengan kadar hemoglobin.

Sama dengan asupan vitamin A, asupan tembaga seluruh atlet yang terolong lebih. Namun, tidak ada hubungan signifikan dengan kadar hemoglobin. Proses absorpsi beberapa metal di usus dilaksanakan oleh "Divalent Metal Transporter 1" (DMT1), termasuk zat besi dan tembaga. Absorpsi zat besi dan tembaga saling berkompetisi satu sama lain. Berdasarkan penelitian lain, $\mathrm{Cu} 1+$ menghambat absorpsi zat besi di sel CaCo-2 dan begitu juga sebaliknya. $\mathrm{Cu}$ dan $\mathrm{Fe}$ berinteraksi di usus melalui kompetisi transpor di enterocytes melalui DMT1. ${ }^{24}$ Hal ini sejalan dengan penelitian Evilcha yang menunjukkan tidak adanya hubungan antara tembaga dengan kadar hemoglobin.

Pada penelitian ini, asupan tannin menunjukkan tidak ada hubungan dengan kadar hemoglobin. Hal ini menunjukkan bahwa tannin merupakan penghambat penyerapan besi. Tanin akan mengikat besi sehingga sulit larut dan sulit untuk diserap dalam tubuh. Begitu juga pada asupan fitat yang tidak menunjukkan hubungan dengan kadar hemoglobin. Asam fitat termasuk dalam kelompok molekul anti-nutrisi karena asam fitat mampu mengikat $\mathrm{Zn}, \mathrm{Fe}, \mathrm{Ca}$, dan $\mathrm{Mg}$ sehingga mineralmineral tersebut tidak dapat diserap oleh sistem pencernaan. Asam fitat akan membentuk presipitat yang sukar larut sehingga mineral tersebut tidak dapat diserap oleh tubuh. ${ }^{22}$

\section{SIMPULAN}

Penelitian ini menunjukkan tingkat kecukupan protein, zat besi, asam folat, vitamin $\mathrm{C}$, dan seng 
kurang dari $100 \%$, sedangkan tingkat kecukupan vitamin A dan tembaga lebih dari $100 \%$. Terdapat hubungan antara tingkat kecukupan protein, zat besi, asam folat dan seng dengan kadar hemoglobin pada atlet sepakbola. Namun, tidak ada hubungan asupan vitamin $\mathrm{C}$, vitamin $\mathrm{A}$ dan tembaga dengan kadar hemoglobin pada atlet sepakbola.

\section{SARAN}

Kadar hemoglobin pada atlet harus selalu tercukupi supaya performa atlet dapat terjaga. Hal itu dapat terpenuhi apabila asupan zat gizi mencukupi kebutuhan atlet, khususnya asupan protein, zat besi, asam folat dan seng untuk mencegah terjadinya anemia. Pihak penyelenggara dipastikan dapat menyediakan makanan sesuai dengan kebutuhan atlet dan membuat makanan tersebur terlihat menarik untuk dikonsumsi para atlet.

\section{DAFTAR PUSTAKA}

1. Sugiyanto. Hubungan Kontribusi Zat Gizi Makanan Sekolah dengan Kadar Hemoglobin Murid SD Islam Integral Luqman Al-Hakim Purwodadi. Skripsi. Universitas Diponegoro. Semarang. 2008.

2. Nurhaedah, Djunaidi.Dachlan, Nurkhawi Nawir. Gambaran Status Gizi Antropometri dan Status Hemoglobin Siswa Sekolah Sepak Bola Anyelir dan Sekolah Sepa Bola Bangau Putra Makassar Tahun 2013. Program Studi Ilmu Gizi Fakultas Kesehatan Masyarakat Universitas Hasanuddin. Makassar. 2013.

3. Tri, Yuni Astuti. Hubungan Asupan Makronutrien dan Kadar Hemoglobin dengan Aktivitas Fisik pada Remaja Putri di Asrama SMA MTA Surakarta. Skripsi. Universitas Muhammadiyah Surakarta. 2013.

4. Hapsari, Mirza. Gaya Hidup, Status Gizi dan Stamina Atlet pada Sebuah Klub Sepakbola. Berita Kedokteran Masyarakat, Vol. 23, No. 4, Desember. Yogyakarta. 2007.

5. Devadas, Rajammal P. Activating The Community for Nutritional Improvement. Food and Nutrition Bulletin, vol. 23, No. 2. The United Nations University. Canada. 2002.

6. Brox et al. Hemoglobin, Iron, Nutrition and Life-Style Among Adolescents in a Coasral and Inland Community In Northern Norway. International Journal of Circumpolar Health 62:2. 4. 2003.

7. Scheers, Natalie. Regulatory Effects of $\mathrm{Cu}, \mathrm{Zn}$, and $\mathrm{Ca}$ on Fe Absorption: The Intricate Play between Nutrient Transporters. Nutrients 5, 957-970. 2013.

8. Cendani, Citta. Hubungan Asupan Mikronutrien dengan Kadar Hemoglobin dengan Kesegaran Jasmani Remaja Putri. Artikel penelitian Program Studi Ilmu Gizi Fakultas Kedokteran Universitas Diponegoro. Semarang. 2010.

9. World Health Organization. Haemoglobin Concentrations for the Diagnosis of Anaemia and Assessment of Severity. Vitamin and Mineral Nutrition Information System. Geneva. 2011.
10. United Nations Children's Fund. Iron Deficiency Anaemia: Assessment, Prevention and Controls. United Nations University. World Health Organization. 2001.

11. Supariasa, I Dewa Nyoman, et al. Penilaian Status Gizi. EGC Penerbit Buku Kedokteran: Jakarta.

12. Soekirman. Ilmu Gizi dan Aplikasinya. Direktorat Jenderal Pendidikan Tinggi, Departemen Pendidikan Nasional : Jakarta. 2000

13. Shinta, Ade Dewi. Efek Penggunaan Suplemen Extra Joss dengan Stamina pada Atlet Sepakbola di Devisi Utama Persatuan Sepakbola Langkat (PSL) Bapor Pertamina Pangkalan Susu Tahun 2010. Skripsi. Fakultas Ksehatan Masyarakan. Universitas Sumatera Utara: Medan. 2010

14. Rusfridra, Ahmad. Protein Hewani untuk Kecerdasan. Sinar Hrapan: Jakarta. 2005.

15. Hoffman Jay, Michael J. Falvo. Protein- Which Is Best. Journal of Sports Science and Medicine 3, 118130. 2004.

16. Iyengar V, Pullakhandam R, Nair KM. Iron-Zinc interaction during uptake in human intestinal Caco-2 cell line: Kinetic analyses and possible mechanism. Indian Journal of Biochemistry and Biophysics 2009; 46: 299-306.

17. Sandström B, Davidsson L, Cederblad A, Lönnerdal B. Oral iron, dietary ligands and zinc absorption. J Nutr. 1985; 115(3): 411-4.

18. Davidsson L, Almgren A, Sandström B, Hurrell RF. Zinc absorption in adult humans: the effect of iron fortification. Br J Nutr. 1995; 74: 417-25.

19. Sandström B. Micronutrient interactions: effects on absorption and bioavailability. Br J Nutr. 2001; 85 Suppl 2: S181-S185.

20. Khomsan, Ali. Pangan dan Gizi untuk Kesehatan. PT Grafindo Persada. Jakarta. 2003.

21. Almatsier, Sunita. 2001. Prinsip Dasar Ilmu Gizi. Gramedia Pustaka Utama. Jakarta

22. Jang JT, Green JB, Beard JL, Green MH. Kinetic analysis shows that iron deficiency decreases liver vitamin $A$ mobilization in rats. $\mathrm{J}$ Nutr 2000;130:1291-1296.

23. Sharp P. The molecular basis of copper and iron interactions. Proc Nutr Soc. 2004; 63(4): 563-9. 